\title{
RELATIONSHIPS BETWEEN PITCH-MATCHING AND GRADE LEVEL, SEX, ETHNICITY, AND CLASSROOM TEACHERS' USE OF MUSIC IN GRADES K-3
}

\author{
$U D C(371.3: 78+781.4)::(78.07: 371.213 .3)+784$
}

\author{
Shelly C. Cooper ${ }^{1}$, Jere T. Humphreys ${ }^{2}$ \\ ${ }^{1}$ University of Arizona, Tucson, Arizona, USA, \\ ${ }^{2}$ Arizona State University, Tempe, Arizona, USA
}

\begin{abstract}
The purpose of this study was to examine relationships between pitch-matching and grade level, sex, ethnicity, and classroom teachers' use of music among $K-3$ students $(N=289)$ taught by the same general music teacher. Portions of the data from a pitchmatching exercise that functioned as the music teacher's roll-taking procedure during the 2005-06 school year were treated as pre-and posttests. There were no significant pretest differences between ethnic groups (Hispanic, White, Other). There were significant pretest differences among classes taught by different classroom teachers, as well as the female students scoring significantly higher than males. Covariance analysis (pretest as covariate) revealed significant improvement by girls over boys on the posttest. There were no significant pretest differences among grade levels, suggesting a lack of carryover of pitch-matching skills from previous years, despite significant improvement (pre-post) for every grade level during the year under study. The boys performed poorly relative to girls in higher grades, though the interaction was not significant. Finally, the study revealed relationships between classroom teachers' reported use of music and student gain scores (pre-post) in pitch-matching.
\end{abstract}

Key words: pitch-matching, echo singing, singing voice, singing voice assessment

Finding the best methods for enhancing children's vocal development, aural acuity, and pitch-matching ability remains a major task for music educators. One important goal for those who provide music instruction, whether a music specialist or a classroom teacher, is to assist children in learning to use their singing voice and to match pitch (MENC, 1994, National Music Standard 1: "Singing, alone and with others, a varied repertoire of music"). Research shows that general music teachers involve students in singing activities for approximately one-third of their instruction time (Baldridge, 1984; Moore, 1981; Weinberg,

Received March 15 2016/ Accepted April 212016

Corresponding author: Jere Humphreys

Arizona State University, Tempe, Arizona,USA

E-mail: Jere.Humphreys@asu.edu 
1988), yet many students are unable to match pitch at reasonable levels of accuracy and consistency (Levinowitz, Barnes, Guerrini, Clement, D’April, \& Morey, 1998).

Numerous researchers have investigated aspects of singing and pitch-matching in elementary general music classes, including teaching methods and techniques as well as learning outcomes (e.g., DeYarman, 1972; Goetze, \& Horii, 1989; Martin, 1991; Rutkowski, 1994). These researchers have reported mixed results for different age groups or grade levels and other demographic categories of students. Cooper (1995) posited that the conflicting research results were due in part to individual studies focusing on a limited number of grade levels.

Most general music method books promote echo singing as a viable technique for teaching songs, reinforcing melodic contour, expanding vocal range, and vocal exploration activities (e.g., Andress, 1980; Campbell \& Scott-Kassner, 2001; Choksy, 1974). Not surprisingly, children learn to sing through direct imitation of a teacher model in most classrooms (Apfelstadt, 1984). Research suggests that imitation can be successful with children as young as three years (Sinor, 1984/1985). Despite the ubiquity of vocal modeling in elementary general classrooms, however, researchers have not been able to identify the most effective type(s) of vocal models for children to imitate. There is some evidence that children experience the most success when matching adult female or child models of either sex (Green, 1990; Sims, Moore, \& Kuhn, 1982; Smith, 1963; Yarbrough, Green, Benson, \& Bowers, 1991). Furthermore, Hendley and Persellin (1996) reported more improvement in singing accuracy among children when they imitated adult male models using a falsetto range than when they imitated the same models using a normal male singing range.

Other questions relating to children's singing remain, particularly in the area of pitchmatching. For example, studies have yielded mixed results over whether children are more accurate when singing alone or in groups. Although Smith (1973/1974) and Green (1994) concluded that students sang more accurately in group unison situations than when singing alone, other researchers have reported that experiences in singing alone appeared to improve children's singing accuracy (Clayton, 1986; Goetze \& Horii, 1989; Joyner, 1971; Smale, 1987/1988). Thus, Goetze's (1985/1986) findings of improved singing accuracy as a result of solo singing activities in grades K-1 are in line with the majority, but not all, of the findings of relevant studies. For example, her finding of no significant difference in singing accuracy for grade 3 subjects is in agreement with Cooper (1995), who reported no significant differences at any grade level (1-5). Cooper speculated that her use of a child model, rather than an adult model, was a contributing factor to the differing results.

Most researchers have reported no significant differences on various singing tasks between male and female subjects (Apfelstadt, 1984; Cooper, 1995; Pedersen \& Pedersen, 1970; Petzold, 1963; Sinor, 1984/1985; Smale, 1987/1988; Welch, Sergeant, \& White, 1995/1996). In studies in which significant differences occurred, females performed more accurately than males regardless of singing task or vocal model (Davies \& Roberts, 1975; Goetze \& Horii, 1989; Green, 1990, 1994; Trollinger, 2003). No studies were found on the effects of ethnicity or classroom teachers' use of music on pitch-matching achievement.

The purpose of this study was to examine relationships between pitch-matching and grade level, sex, ethnicity, and classroom teachers' use of music among K-3 students taught by the same general music teacher. Four research questions paralleled these purposes and guided the study. When following a traditional Kodály-based general music curriculum that incorporates multiple opportunities for solo singing, use of solfege and hand signs, limited singing with CDs/recordings, and utilization of singing games: (a) Is there a difference 
in vocal pitch-matching ability as a function of grade level of the subjects? (b) Is there a difference in vocal pitch-matching ability as a function of sex of the subjects? (c) Is there a difference in vocal pitch-matching ability as a function of ethnicity of the subjects? (d) Is there a relationship between vocal pitch-matching ability and classroom (not music) teachers' use of music with the students?

\section{METHOD}

The study was conducted in a K-6 public elementary school in a large city in the southwestern United States. The school's enrollment during the 2005-06 school year was 945,733 of whom remained enrolled for the entire year. The racial/ethnic composition of the school was $69.4 \%$ Hispanic, 16.8\% White, 8.4\% African American, 4.7\% Native American, and $.8 \%$ Asian. Forty-eight percent of students in this study were female. Nine percent of the school's students received services through special education and special programs, and $83.4 \%$ qualified for free or reduced lunches. Some $48.7 \%$ were students with English as their first language, $39 \%$ lived in single-family homes, and $35 \%$ lived in singleparent families.

The study included $\mathrm{K}-3$ students $(N=496)$ from all 17 regular classes taught as intact music classes by the principal author of this study, the site-based general music specialist for the school during the 2005-06 school year. The use of the regular general music specialist for both the teaching and research components of this study should be considered a positive aspect of the design (Campbell \& Stanley, 1963). This general music specialist rated each student's ability to match (echo) her sung model pitches, so-mi $\left(\mathrm{A}^{3}, \mathrm{~F} \#^{3}\right)$ in a 4beat pattern, at various times throughout the school year (a 38-week span). Students were asked to sing within a narrow range because it aligned with the frequency range of their speech (D-A) and the limited movement of their larynx (Trollinger, 2003). The range from $\mathrm{Bb}^{3}$ to $\mathrm{Db}^{4}$ was avoided because children experience difficulty in that range (Gordon, 1971, 1979; Young, 1971). Short melodic patterns were used, which are easier for children to sing than longer patterns (Sims, Moore, \& Kuhn, 1982). Students were scored as follows: $4=$ matched pitch (could be slightly sharp or flat), $3=$ used singing voice but sang incorrect pitches, $2=$ used speaking voice, $1=$ no response.

Each regular class in grades 1-3 participated in one 40-minute music class per week, while kindergarten students attended two 20-minute music classes per week. Each music class began with vocalization/vocal exploration activities, followed by a rhythm/beatkeeping exercise. Flowers and Dunne-Sousa (1990) noted that children are likely to expand their vocal ranges "when modeling brief pitch patterns" and recommended implementing "welcome warm-ups" specifically designed for that purpose (p. 110). The students were then asked to echo the 4-beat so-mi pattern as a component of the roll-taking (attendance) process, and as an attempt to reduce performance anxiety. The activity became an integral part of the music class routine throughout the year, including days when assessments were not recorded. A tuning fork or piano served as the pitch reference at the beginning of each echo exercise. To control for order of presentation, students were called on to respond in various orders throughout the year.

The pitch-matching test results from weeks 2 and 3 and those from weeks 37 and 38 of the academic year were designated as the pretest and posttest, respectively. When scores were available from both weeks in a given pair (i.e., weeks 2-3 and 37-38), the means of the 
two weeks (dual data points) were used for individual subjects, resulting in an adjusted preand post-test score; when scores from only one week were available, the lone scores (single data points) were used, resulting in an unadjusted posttest score. Scores were analyzed only for subjects for whom there were complete data sets (i.e., at least one pretest and one posttest score). The number of students per intact class with complete, usable data sets ranged from $n=14-22$. The final sample consisted of kindergarten ( 6 classes, $n=97)$, grade 1 ( 3 classes, $n=50$ ), grade 2 ( 4 classes, $n=77$ ), and grade 3 ( 4 classes, $n=65$ ). The total number of subjects $(N=289)$ included 167 boys $(57.8 \%)$ and 122 girls $(42.2 \%)$. The ethnic breakdown was Hispanic $(n=213,73.7 \%)$, White $(n=40,13.8 \%)$, Black $(n=25$, $8.7 \%)$, Native American $(n=8,2.8 \%)$, and Asian-Pacific $(n=3,1.0 \%)$. To achieve sufficient group and cell sizes for the analysis, the smallest three ethnic groups were combined to form a new category, which resulted in three composite categories: Hispanic $(n=213,73.7 \%)$, White $(n=40,13.8 \%)$, and "Other" $(n=36,12.5 \%)$.

During weeks 37-38 (the posttest period), 14 of the 17 classroom teachers completed a 5-question written survey about the frequency of their use of certain music activities with their respective classes, and estimates of their students' music-making activities outside the classroom, for a response rate of $82.4 \%$. Specifically, the classroom teachers were asked to indicate their level of agreement with the following five statements: (a) "I play music (CDs, Radio, etc.) in my classroom"; (b) "I play an instrument(s) in my classroom (guitar, piano/keyboard, etc.)"; (c) "I sing with my students in the classroom"; (d) "I hear my students sing in the classroom (that is, spontaneous student singing without adult encouragement)"; and (e) "I hear my students sing outside the classroom (e.g., playground, in line, lunchroom, but not in music class)." The response scale was "never," "sometimes," "often," and "always," coded 1-4, respectively.

\section{RESULTS}

Analysis of variance (ANOVA) results revealed no significant pretest differences in pitch-matching scores among the four grade levels $(\mathrm{K}-3)(F=1.280, d f=3,285, p<.282$, partial $\eta^{2}=.013$, Levene's $\left.F=3.175, p<.025\right)$. Non-parametric ANOVA (KruskallWallis) results revealed no significant pretest differences among the five ethnic groups $\left(\chi^{2}=\right.$ 3.824, $d f=4, p<.430$ ). Similarly, a parametric ANOVA showed no significant pretest differences among the three composite ethnic groups $(F=1.943, d f=2,286, p<.145$, partial $\eta^{2}=.013$, Levene's $F=2.786, p<.063$ ) (Table 1 ).

There were significant pretest differences among classes of the 17 teachers (ANOVA $F=3.559 ; d f=16,272, p<.000$, partial $\eta^{2}=.173$, Levene's $\left.F=1.764, p<.036\right)$, and also as a function of sex, with girls scoring significantly higher than boys (ANOVA $F=5.247$, $d f=1,287, p<.023$, partial $\eta^{2}=.017$, Levene's $\left.F=3.206, p<.074\right)$. Consequently, the authors employed analysis of covariance (ANCOVA) tests in the next phase of the analysis, with the pretest as the covariate and the (adjusted) posttest as the dependent variable. There was a significant correlation between the pretest and (unadjusted) posttest scores $(r=.196$, $d f=287, p<.001$ ), as well as a significant difference between the pretest and (unadjusted) posttest means in favor of the posttest $(t=-13.677, d f=288, p<.000)$ (Table 1$)$. 
Table 1 Means and Standard Deviations for Pretest and Unadjusted Posttest $(N=289)$

\begin{tabular}{|c|c|c|c|c|c|}
\hline \multirow{2}{*}{ Variable } & \multirow{2}{*}{$n$} & \multicolumn{2}{|c|}{ Pretest (Covariate) } & \multicolumn{2}{|c|}{ Posttest (Unadjusted) } \\
\hline & & Mean & $S D$ & Mean & $S D$ \\
\hline \multicolumn{6}{|l|}{ Grade } \\
\hline $\mathrm{K}$ & 97 & 2.505 & .747 & 3.284 & .462 \\
\hline 1 & 50 & 2.600 & .904 & 3.310 & .614 \\
\hline 2 & 77 & 2.776 & .821 & 3.370 & .547 \\
\hline 3 & 65 & 2.569 & .684 & 3.169 & .741 \\
\hline \multicolumn{6}{|l|}{ Ethnicity } \\
\hline Hispanic & 213 & 2.545 & .742 & 3.242 & .584 \\
\hline Other & 36 & 2.694 & .856 & 3.375 & .637 \\
\hline White & 40 & 2.775 & .742 & 3.438 & .509 \\
\hline \multicolumn{6}{|l|}{ Sex } \\
\hline Male & 167 & 2.509 & .702 & 3.210 & .587 \\
\hline Female & 122 & 2.713 & .808 & 3.389 & .566 \\
\hline \multicolumn{6}{|l|}{ Teacher } \\
\hline A & 15 & 2.600 & .737 & 3.667 & .488 \\
\hline B & 21 & 2.238 & .436 & 2.810 & .680 \\
\hline $\mathrm{C}$ & 21 & 2.439 & .870 & 3.381 & .498 \\
\hline $\mathrm{D}$ & 19 & 3.211 & .713 & 3.421 & .607 \\
\hline E & 16 & 2.625 & .719 & 3.594 & .417 \\
\hline $\mathrm{F}$ & 17 & 2.294 & .686 & 3.382 & .600 \\
\hline G & 15 & 2.933 & .799 & 3.200 & .775 \\
\hline $\mathrm{H}$ & 18 & 2.833 & .515 & 3.444 & .616 \\
\hline I & 16 & 3.313 & .793 & 3.281 & .632 \\
\hline $\mathrm{J}$ & 14 & 2.571 & .514 & 3.214 & .378 \\
\hline K & 14 & 2.643 & .633 & 3.143 & .770 \\
\hline $\mathrm{L}$ & 22 & 2.500 & .802 & 3.364 & .492 \\
\hline M & 17 & 2.294 & .772 & 3.088 & .404 \\
\hline $\mathrm{N}$ & 14 & 2.143 & .949 & 3.071 & .616 \\
\hline $\mathrm{O}$ & 17 & 2.647 & .496 & 3.265 & .472 \\
\hline $\mathrm{P}$ & 18 & 2.444 & .616 & 3.139 & .413 \\
\hline Q & 15 & 2.467 & .743 & 3.433 & .530 \\
\hline Total & 289 & 2.595 & .754 & 3.286 & .584 \\
\hline
\end{tabular}

A one-way ANCOVA revealed no significant differences in adjusted posttest means among grade levels $\left(F=1.204, d f=3,285, p<.309\right.$, partial $\eta^{2}=.013$, Levene's $F=7.145$, $p<.000)$, although there was a lack of homogeneity of variance among cells. There were also no significant differences as a function of ethnicity $(F=1.698, d f=2,286, p<.185$, partial $\eta^{2}=.012$, Levene's $\left.F=.722, p<.487\right)$. However, there were significant adjusted posttest differences among classes taught by different teachers $(F=2.196, d f=16,272, p<$ .006 , partial $\eta^{2}=.115$, Levene's $F=2.552, p<.001$ ), but with a lack of homogeneity of variance. There was also a significant difference as a function of sex, again in favor of girls $\left(F=4.891, d f=1,287, p<.028\right.$, partial $\eta^{2}=.017$, Levene's $\left.F=.011, p<.916\right)$.

The three-way and most of the two-way interactions present in this design were not analyzed due to cell size limitations $(n<5)$. Moreover, the teacher and grade level variables were not crossed. The two remaining two-way interactions were not significant: sex by ethnicity $\left(F=.219, d f=5,283, p<.803\right.$, partial $\eta^{2}=.002$, Levene's $F=1.289$, $p<.269)$, and grade by sex $\left(F=2.152, d f=7,281, p<.094\right.$, partial $\eta^{2}=.022$, Levene's 
$F=2.856, p<.007)$. The grade by sex interaction suggests that boys performed less well than girls in the upper grades, although it failed to reach statistical significance (Figure 1).

Estimated Marginal Means of POSTTEST

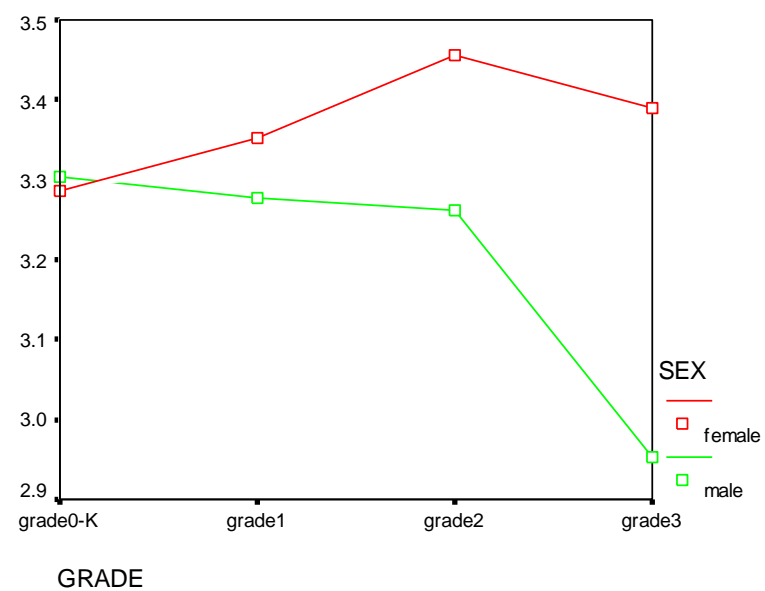

Fig. 1 Interaction between Grade Level and Sex of Students (non-significant, $p<.094$ )

The highest mean score on the teacher survey was for the teacher playing recordings in class, followed in descending order by the teacher singing with students in class, the teacher listening to students sing in class, the teacher hearing students sing outside of class, and the teacher playing instruments in class (Table 2). All 14 responding teachers indicated that they never played musical instruments for their students, so that item was removed from the analysis and the four remaining items were combined into a scale. The composite scores for this 4-item scale could range from 4 - 16 (1-4 points for each of four items). There were moderate to strong intercorrelations among the four survey items $(r=.629-.822, p<.000)$. Internal consistency (Chronbach's alpha) for the scale was high at $\infty=.91$.

Zero-order correlations between the four individual survey/scale items and gain scores (unadjusted posttest minus pretest scores) ranged from $r=.058-.167$, with three of the four being statistically significant $(p<.05)$ (Table 2$)$. The correlation between the composite scale and gain scores was $r=.148(p<.05)$. A stepwise multiple regression model with three music activity variables from the teacher survey predicted $5 \%$ of variance in gain scores: the teacher listens to students sing in class, the teacher hears students sing outside of class, and the teacher plays recordings in class. Adding the teacher sings with students in class variable to the model resulted in no additional variance accounted for in the dependent variable (Table 2). 
Table 2 Means, Standard Deviations, and Correlations (Zero-Order and Multiple) between Reported Regular Classroom Music Activities and Gain Scores $(N=240)$

\begin{tabular}{|c|c|c|c|c|}
\hline Survey Item & $M$ & $S D$ & $r$ & $p$ \\
\hline Play recordings in class & 2.94 & .971 & .147 & .023 \\
\hline Sing with students in class & 2.54 & 1.026 & .144 & .026 \\
\hline Listen to students sing in class & 2.29 & 953 & 167 & .010 \\
\hline Hear students sing outside class & 2.15 & .730 & .058 & .372 \\
\hline Play instruments in class & 1.00 & .000 & .000 & 1.000 \\
\hline \multicolumn{5}{|c|}{ Regression model } \\
\hline Variable & $\mathrm{SC} \beta$ & $t$ & $p$ & $R^{2}$ \\
\hline Model 1 & & & & .028 \\
\hline Hear students sing in class & .167 & 2.611 & .010 & \\
\hline Model 2 & & & & .039 \\
\hline Hear students sing in class & .286 & 2.946 & .004 & \\
\hline Hear students sing outside class & .158 & -1.625 & .105 & \\
\hline Model 3 & & & & .050 \\
\hline Hear students sing in class & .247 & 2.494 & .013 & \\
\hline Hear students sing outside class & -.236 & -2.209 & .028 & \\
\hline Play recordings in class & .155 & 1.718 & .087 & \\
\hline
\end{tabular}

\section{CONCLUSIONS}

Probably the most important finding in this study was that elementary classroom teachers' employment of certain music activities, in class and out, related to their students' pre-post increases in pitch-matching skills. The self-report on teacher use of certain musical activities predicted only $5 \%$ of variance in achievement gains, but small, incremental improvements in student achievement can result in significant aggregate results in music education (Humphreys, 2006). Listening to students sing in class, playing recordings in class, and singing with students in class were all correlated significantly with improvements in pitch matching, and hearing students sing outside of class entered the final regression model. Data from this study failed to demonstrate any effects from instrument usage in class due to lack of variance. According to Saunders and Baker (1991), many classroom teachers receive limited musical training in their pre-service teacher education programs and consequently lack the skills and confidence to perform for their students. Future studies should corroborate and find additional reasons, if any, why many regular classroom teachers (all in this study) fail to play instruments for their students in class.

Given the simplicity of the pitch-matching task and assessment procedure employed in this study, a corroborating judge was not needed. However, the limited range of the 4point scale, with few 1's actually awarded, resulted in limited variance in test scores, which might account for some of the non-significant results, and probably contributed to the lack of homogeneity in variance among some groups and cells. Until replication studies can be conducted, readers should use caution when interpreting ANOVA and ANCOVA results based on unequal group and cell variances. 
Statistically significant gains in pitch-matching achievement occurred between the beginning and end of the school year (pretest and unadjusted posttest) at all four grade levels: kindergarten $(t=-10.571, d f=96, \mathrm{p}<.000)$, grade $1(t=-5.124, d f=49, p<.000)$, grade $2(t=-6.080, d f=76, p<.000)$, grade $3(t=-5.609, d f=64, p<.000)$. However, there were no significant pretest differences among grade levels. This begs the question as to how much, if any, year-to-year carryover occurred in these students' pitch-matching ability. Did students at the beginning of each year revert to their achievement level from the beginning of the previous year? Did the achievement gains identified in this study result from the abilities of the music specialist, a teacher with more than 20 years of experience but who was in her first year at this particular school? Were the significant gains due to the Hawthorne Effect?

Another set of questions concerns the effects of sex of the subjects on pitch-matching achievement. Even with the advantage of significantly higher scores on the pretest, the ANCOVA analysis revealed a significantly larger increase for girls than boys in the adjusted posttest scores. The interaction between the grade level and sex variables was not significant, but it neared significance $(p<.094)$ and might well have reached significance had there been more variance in the performance test scores (Figure 1). Even though the interaction failed to reach significance, this finding tends to support previous research findings of increasing superior achievement in successively higher grades by girls in relation to boys in general music classes.

The assessment procedure employed in this study could be useful to general music practitioners. With the influx of national, state, and district standards and the pressure to quantitatively demonstrate accountability and student progress, general music specialists often struggle with ways to incorporate meaningful assessment into their routines. Since the appearance of Boardman's (1964) first rating scale for assessing singing in elementary general music, many different assessment tools for measuring the singing voice have been developed (DeYarman, 1972; Dittenmore, 1969; Feirerabend, 1984; Hale (Runfola), 1977; Ramsey, 1982; Roberts \& Davies, 1975; Rutkowski, 1990; Young, 1971). However, many of these tools are cumbersome and time-consuming, rendering them problematic for practical use in the general music classroom.

Levinowitz et al. noted the need for continued development of singing in general music. After their review of singing in the elementary general music curriculum, they posited that: ". . . a practical tool for evaluation should be easy to internalize and use on a regular basis during the classroom process by the classroom music teacher" $(1998,37)$. More straightforward assessment processes, such as the one used in this study, may prove more practical and therefore more useful than some developed in earlier years. In this case, students thought the teacher was merely taking attendance, whereas she was also tracking student progress with minimal intrusion on instructional time because the assessment was embedded in the procedural and instructional routines.

Future research designs with control groups might provide insights into these and other questions. For example, does a classroom teacher who values music and encourages musicmaking in the classroom somehow lead students to match pitches more accurately? It might prove informative in the future to employ research designs with multiple experimental groups wherein types of regular classroom music activities, such as instrument usage, could be controlled. Longitudinal studies on the same students from year to year could provide answers to other questions raised in this study. 


\section{REFERENCES}

Chomsky Apfelstadt, H. (1984). Effects of melodic perception instruction on pitch discrimination and vocal accuracy of kindergarten children. Journal of Research in Music Education, 32, 15-24.

Andress, B. (1980). Music experiences in early childhood. New York: Holt, Rinehart \& Winston.

Baldridge, W. R. (1984). A systematic investigation of listening activities in the elementary general music classroom. Journal of Research in Music Education, 32, 79-93.

Campbell, P. S., \& Scott-Kassner, C. (2001). Music in childhood: From preschool through the elementary grades. New York: Schirmer Books.

Campbell, D. T., \& Stanley, J. C. (1963). Experimental and quasi-experimental designs for research. Chicago: Rand McNally College Publishing Company.

Choksy, L. (1974). The Kodály Method. Englewood Cliffs, NJ: Prentice-Hall.

Clayton, L. (1986). An investigation of the effect of a simultaneous pitch stimulus on vocal pitch accuracy. Unpublished master's thesis, Indiana University.

Cooper, N. A. (1995). Children's singing accuracy as a function of grade level, gender, and individual versus unison singing. Journal of Research in Music Education, 43, 222-231.

DeYarman, R. M. (1972). An experimental analysis of the development of rhythmic and tonal capabilties of kindergarten and first grade children. In E. E. Gordon (Ed.), Experimental Research in the Psychology of Music: 8 (1-44). Iowa City, IA: University of Iowa Press.

Dittenmore, E. E. (1969). An investigation of some musical capabilities of elementary school students. Dissertation Abstracts International, 29, 4516A. (University Microfilms No. DA8410243)

Feierabend, J. M. (1984). The effects of specific tonal pattern training on singing and aural discrimination abilities of first grade children. Dissertation Abstracts International, 45, 110A. (University Microfilms No. DA8410243)

Flowers, P. J., \& Dunne-Sousa, D. (1990). Pitch-pattern accuracy, tonality, and vocal range in preschool children's singing. Journal of Research in Music Education, 38, 102-114.

Goetze, M. (1986). Factors affecting accuracy in children's singing (Doctoral dissertation, University of Colorado, 1985). Dissertation Abstracts International, 46, 2955A.

Goetze, M., \& Horii, Y. (1989). A comparison of the pitch accuracy of group and individual singing in young children. Bulletin of the Council for Research in Music Education, 99, 57-73.

Gordon, E. E. (1971). The psychology of music teaching. Englewood Cliffs, NJ: Prentice Hall, Inc.

Gordon, E. E. (1979). Primary Measures of Music Audiation. Chicago: G.I.A. Publications, Inc.

Green, G. A. (1990). The effect of vocal modeling on pitch-matching accuracy of elementary schoolchildren. Journal of Research in Music Education, 38, 225-231.

Green, G. A. (1994). Unison versus individual singing and elementary students' vocal pitch accuracy. Journal of Research in Music Education, 42, 105-114.

Hale, M. (Runfola). (1977). An experimental study of the comparative effectiveness of harmonic and melodic accompaniment in singing as it relates to the development of a sense of tonality. Bulletin of the Council for Research in Music Education, 53, 23-30.

Humphreys, J. T. (2006). 2006 Senior Researcher Award Acceptance Address: Observations about music education research in MENC's first and second centuries. Journal of Research in Music Education, 54, 183-202.

Levinowitz, L. M., Barnes, P., Guerrini, S., Clement, M., D’April, P., \& Morey, M. J. (1998). Measuring singing voice development in the elementary general music classroom. Journal of Research in Music Education, 46, 35-47.

Martin, B. E. (1991). Effects of hand signs, syllables, and letters on first grader's acquisition of tonal skills. Journal of Research in Music Education, 3, 161-170.

Moore, R. S. (1981). The comparative use of teaching time by American and British elementary music specialists. Bulletin of the Council for Research in Music Education, 66-67, 62-68.

Ramsey, J. H. (1982). An investigation of the effects of age, singing ability, and experience with pitched instruments on the melodic perception of preschool children. Dissertation Abstracts International, 42, 3053A. (University Microfilms No. 8128451)

Roberts, E., \& Davies, A. D. M. (1975). The response of "monotones" to a program of remedial training. Journal of Research in Music Education, 23, 227-239.

Rutkowski, J. (1990). The measurement and evaluation of children's singing voice development. The Quarterly Journal of Music Teaching and Learning, 1, 81-95.

Rutkowski, J. (1994). The longitudinal effectiveness of individual/small group singing activities on children's use of the singing voice and developmental music aptitude. Bulletin of Research in Music Education, 20, 31-43. 
Saunders, T. C., \& Baker D. S. (1991). In-service classroom teachers' perceptions of useful music skills and understandings. Journal of Research in Music Education 39, 248-261.

Sims, W. L., Moore, R. S., \& Kuhn, T. L. (1982). Effects of female and male vocal stimuli, tonal pattern length, and age on vocal pitch-matching abilities of young children from England and the United States. Psychology of Music, Special Issue, 104-108.

Sinor, E. (1984). The singing of selected tonal patterns by preschool children (Doctoral dissertation, Indiana University).

Smale, M. J. (1988). An investigation of pitch accuracy of four- and five-year-old singers (Doctoral dissertation, University of Minnesota, 1987). Dissertation Abstracts International, 48, 2013A.

Smith, R. B. (1963). The effect of group vocal training on the singing abilities of nursery school children. Journal of Research in Music Education, 11, 137-141.

Trollinger, V. (2003). Relationships between pitch-matching accuracy, speech fundamental frequency, speech range, age, and gender in American English-speaking preschool children. Journal of Research in Music Education, 51, 78-94.

Weinberg, P. T. (1988). A descriptive study of music teachers' verbal behavior during the teaching of a new song. Unpublished master's thesis, University of Texas at Austin.

Young, W. T. (1971). An investigation of the singing abilities of kindergarten and first-grade children in East Texas (Report No. PS-006-178). Nacogdoches, TX: Stephen F. Austin State University. ERIC \#:ED069431

\section{VEZA IZMEĐU REPRODUKOVANJA ZADATOG TONSKOG NIZA I RAZREDA, POLA, ETNIČKE PRIPADNOSTI I METODA KORIŠĆENJA MUZIKE U NASTAVI NA PREDŠKOLSKOM UZRASTU I U PRVA TRI RAZREDA OSNOVNE ŠKOLE}

Cilj rada je bio da se ispita veza između reprodukovanja zadatog tonskog niza i razreda koje dete pohađa, pola, etničke pripadnosti i načina na koji nastavnici razredne nastave koriste muziku $u$ nastavi kod predškolske grupe i učenika od prvog do trećeg razreda $(N=289)$ kojima predaje isti nastavnik muzike opšteg smera. Podaci dobijeni na bazi vežbe za reprodukovanje zadatog tonskog niza koje je nastavnik muzike koristio u procesu prozivke učenika tokom školske 2005/06. godine su delom iskorišćeni kao predtestiranje i post-testiranje. U predtestiranju nije bilo značajnijih razlika među etničkim grupama (Hispanjolci, belci, ostali). Značajne razlike u predtestiranju evidentirane su između odeljenja kojima su predavali različiti nastavnici razredne nastave, a bilo je primetno $i$ da su rezultati devojčica bili značajno viši u odnosu na dečake. Analizom kovarijanse (sa predtestiranjem kao kovarijantom) u post-testiranju je utvrđeno značajno poboljšanje kod devojčica u odnosu na dečake. U predtestiranju nije bilo značajnijih razlika između različitih razreda, što je sugerisalo da nije bilo prenošenja veštine reprodukovana zadatog tonskog niza iz prethodnih razreda, i pored značajnog poboljšanja (predtestiranje - post testiranje) u svakom razredu tokom referentne godine. Dečaci su imali slabije rezultate u odnosu na devojčice u višim razredima, iako interakcija nije bila važna. Konačno, studija je ukazala na vezu koja postoji između načina na koji su nastavnici razredne nastave koristili muziku u nastavi i napretka koji su učenici pokazali u pogledu reprodukovanja zadatog tonskog niza (predtestiranje-post-testiranje).

Ključne reči: reprodukovanje zadatog tonskog niza, "eho” pevanje, pevački glas, procena glasa 